
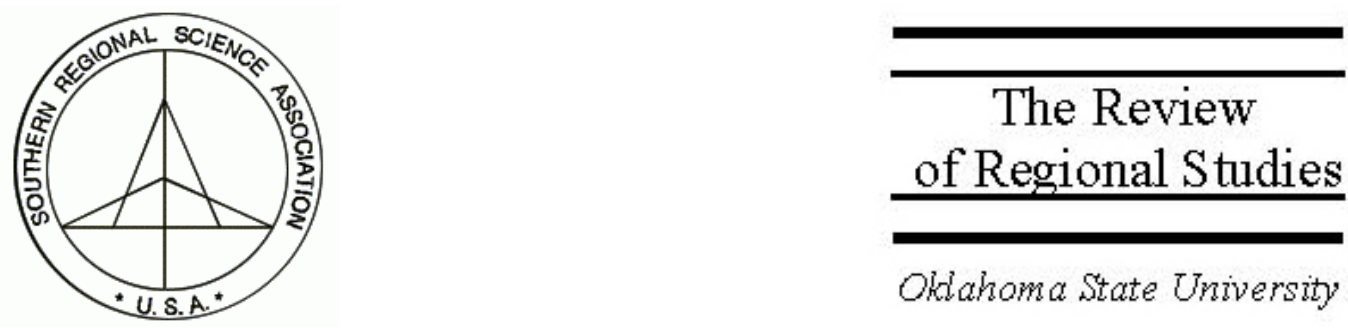

\title{
Revisiting Tourism Regional Economic Impact: Accounting for Secondary Household Employment
}

\author{
David W. Hughes
}

Department of Applied Economics \& Statistics, Clemson University, Clemson Institute for Economic and Community Development, Sandhill Research and Education Center, PO Box 23205, Columbia, SC 29224-3205, e-mail: dhughe3@clemson.edu

\section{Martin Shields}

Department of Economics, C-324 Clark Building, Colorado State University, Fort Collins, CO 80523, e-mail: martin.shields@colostate.edu

\begin{abstract}
Many argue that tourism development is beneficial for local economies, partly because of spillover effects. Others hold that tourism jobs are lower paying, often seasonal, and can generate a host of social ills with earned income concentrated in low-income households. A Social Accounting Matrix (SAM) of a Pennsylvania region is used to test the impacts of tourism businesses supported by the Progress Fund, a regional Community Development Financial Institution, on household income distribution by incorporating secondary and primary employment based income. Analysis indicates that tourism-oriented activity has relatively large contributions to lower and upper as opposed to middle income households.
\end{abstract}

Keywords: Tourism; Secondary employment; Income distribution

JEL Classification: R11; R12; R15 


\section{INTRODUCTION}

Because of long-term declines in natural resource extraction and manufacturing, a number of rural development advocates urge rural communities to take advantage of the economic opportunities afforded by a strong tourism sector (Dawson and Brown 1989). Indeed, for some rural places, tourism may be the only viable growth option. Besides creating jobs and bringing in outside money, tourism-based businesses are often environmentally clean and can help diversify the local economic base, making an economy less vulnerable during economic downturns. Further, tourism development can be equivalent to small business development, which is generally viewed as an attractive means of facilitating local economic growth.

Alternatively, a significant literature questions tourism's desirability because it primarily generates lower-paying, more transient jobs (e.g., Wagner 1997). Critics contend that growth in tourism employment not only has negative effects on regional household income distribution, but such strategies can introduce a host of social ills into a given place. Although tourism's limitations are often acknowledged, proponents believe that the emphasis on low-paying job generation has been exaggerated by those opposed to tourism development.

While the debate is contentious, tourism's actual impact on income distribution has not been well documented, mainly as a result of the lack of analytical tools. Certain models of local or regional economies can be used to shed light on this issue, however. In this paper we develop and implement one such model-a social accounting matrix (SAM) - to assess the economic and income distributional impacts of businesses supported by the Progress Fund, a Pennsylvania-based Community Development Financial Institution (CDFI) specializing in lending to tourism-based businesses and active in a 31-county (rural) region of the state. ${ }^{1}$ Overall, we find that tourism-based businesses supported by the Progress Fund make a substantial contribution to the regional economy in terms of generating employment and income. We also find that much of this income is generated by second jobs for local households. Finally, we find that this additional income is concentrated in relatively low- and high-income households compared to alternative growth scenarios.

In the next section, our discussion centers on the pertinent literature concerning the impact of tourism on economic and community development, with an emphasis on income distribution. We then describe our method for examining such impacts on the region of Pennsylvania in which the Progress Fund operates. Results are then presented, followed by conclusions.

\footnotetext{
${ }^{1}$ Their current mission statement is as follows: "The Progress Fund creates economic opportunity by lending needed capital and providing entrepreneurial coaching to small businesses in the travel \& tourism industry in Pennsylvania, West Virginia, and Appalachian Ohio” (Progress Fund Website 2007). The entrepreneurial coaching takes the form of extensive training and business support services for clients (i.e., firms they have provided with collateral-backed capital).
} 


\section{LITERATURE DISCUSSION}

As an economic development strategy, tourism has been especially embraced by resource-dependent rural areas and smaller metropolitan communities (Dawson and Brown 1989). This arises from the fact that many of the traditional economic bases in rural and small communities have suffered from a number of local and global challenges, including depletion of their natural resource base, a continuing substitution of capital for labor in the production of primary products that reduces the resident workforce and population, pressure from international competition, and restrictions on resource use due to environmental concerns. In response, many communities have turned to tourism as an alternative means of selling something to the outside world, hence maintaining economic activity.

While the economic issues underlying tourism development are relatively straightforward, developing a practical understanding of the industry is challenging because it is difficult to define. One of the most pressing issues is that there is no clear cut tourism sector in published data sources. Instead, tourism activity is captured as a subset of a variety of economic industries, such as transportation, accommodations, food and beverage services, recreational activities, retail shopping, and entertainment. Further hampering our ability to define the industry is the fact that there are many reasons people travel, although tourists are typically defined from the local perspective as people who travel to a community for any purpose. Whatever the reason for traveling, visitors have needs and wants that offer opportunities for the community to create economic benefit. A community tourism industry may therefore be defined as a collection of businesses that creates sales of goods and services to tourists (Minnesota Extension Service 1991).

Rural development experts urge communities using tourism as a development strategy to include business development and expansion programs to maximize the industry's economic impact (Minnesota Extension Service 1991). Because most businesses serving the traveling public are considered small businesses, they should be the focus of these efforts. ${ }^{2}$ This is already recognized in at least some rural areas, where tourism promotion is equivalent to small business promotion (Fleischer and Felsenstein 2000, Fleisher and Pizam 1997); yet in other places government-sponsored economic development efforts have given little attention to small businesses. Ignoring small business needs may be short-sighted from an equity perspective, however, as small tourism businesses can generate employment opportunities for workers who have few alternatives. In particular, proponents argue that small- and medium-size tourism enterprises make surprisingly strong contributions to the employment base (Wanhill 2000).

\footnotetext{
${ }^{2}$ For example, in 1982 there were nearly 336,000 firms in the travel industry, with 98 percent classified as small businesses (Minnesota Extension Service 1991). More currently, as of 2005 for example, 97.4 percent of travel agencies and 96.5 percent of tour operating businesses are considered to be small businesses (U.S. Department of Commerce, Small Business Association, 2005).
} 
Tourism advocates argue that travel spending and investment directly create millions of jobs and are a dynamic catalyst for employment in a myriad of other industries that support or supply travelers and travel companies (Lipman 1997). Additionally, they claim that tourism can serve as a means for revitalizing depressed areas, such as a downtown (Dawson and Brown 1989). A more general argument is that a properly directed tourism program can be used to attract new industry and residents to an area.

The positive view of tourism's contribution to economic development has been disputed, however. While proponents point to the industry's direct and indirect impacts on employment and local income, critics argue that these jobs are poor quality because they tend to be seasonal (Albrecht 2000, Fleischer and Felsenstein 2000, Frederick 1993). Critics further contend that employment estimates may be inflated. Additionally, many policy makers believe that the travel and tourism industries provide low-skill, low-wage primarily service sector jobs. Albrecht (2000) notes that an increased reliance on service sector jobs can lead to a number of problems, such as higher than average poverty rates, social ills due primarily to the transient nature of tourism employment, and few employment opportunities for male workers. Albrecht then points to research indicating that rural economies that depend on service jobs tend to have higher poverty rates than areas that depend on other forms of employment (Garrett, Ng'andu, and Ferron 1994, Jensen and Eggebeen 1994, Goreham 1992). Some also argue economic dependency on service sector jobs contributes to income differences in urban versus rural locations (Jensen and Tienda 1989, Lichter 1989). Noting that service sectors tend to employ female workers, some researchers argue that economic dislocation and lower marriage rates are more prevalent in communities where service sector jobs predominate (Albrecht 1998). In a case study of Wayne County, Utah, which experienced a transition from an agricultural to a tourism-based economy, Albrecht (2000) points to higher rates of family breakup, a rise in crime, and a decline in community-based activities such as Little League as the importance of service sector employment grew.

When looking at tourism's impact on income distribution, previous studies show mixed effects. Wagner (1997) used a SAM to estimate the economic impact of tourism in Brazil's northeastern state of Parana', finding that the sector's regional impact was small because most inputs, commodities, and capital were imported. While the sector provided a reasonably sized employment base, spending was concentrated in sectors where most jobs were low paying. Hence, tourism was seen as being unable "to break the cycle of deficit spending by local households" (p. 606). From this, he concluded that further growth would not provide an incentive for local households to buy into ecosystem tourism and protection of critical habitat.

Other studies paint a more mixed picture concerning tourism's benefits, especially regarding its effects on income distribution. Lee and Kang (1999) examined this issue in Korea using Gini coefficient and Lorenz curve analysis, and found that tourism provided a more equal contribution to income distribution than the finance and social services sectors, but less equal than primary sectors such as mining and electricity generation. One 
important benefit of providing primary low-wage jobs was absorbing semi-skilled and unskilled workers, who were often female.

In their study of a Wisconsin regional economy, Leatherman and Marcouiller (1999) found that tourism growth generated higher aggregate household income in comparison to agricultural production, agricultural processing, timber production, and wood processing. This result held because of tourism's heavy reliance on labor inputs, which in turn supported spending by households in the local economy. With respect to income distribution, tourism showed the highest percent returns to high (greater than $\$ 40,000$ ) and low (less than \$20,000) income classes compared to the three other growth scenarios. Based on this result from their SAM, Leatherman and Marcouiller argue that further developing local tourism activity could lead to a "hollowing out" of income in the local economy, where income is increasingly distributed to lower- and upper-income classes as opposed to the middle-income class. In contrast, the Marcouiller, Kim, and Deller (2004) study of the Great Lakes states suggested that tourism can lead to a more equal distribution of income, at least for water-related tourism activity. They also argued that evaluations of the impact of tourism on income distribution require a more complete socioeconomic breakdown.

Our work is a step in this direction. Specifically, we adhere to the idea that evaluations of tourism's economic and distributional impacts should be theoretically rooted in the household decision-making process. By doing so, we more accurately reflect how resource, specifically labor, allocation decisions are made. We premise this argument on the understanding that households, rather than individuals, are the economy's basic economic unit in consumption and labor market participation decisions. Accordingly, labor force participation decisions are usually made at the household rather than individual level.

In terms of applications, this approach can improve the accuracy of regional impact models, especially for models focusing on distributional impacts. In particular, we argue that the employment and income generated by various sectors of the tourism economy should be distinguished in terms of both secondary and primary sources of household employment. That is, many jobs make secondary contributions to household income. Treating these jobs as primary sources of employment means that household spending by income class can be misspecified. For example, a secondary job that generated $\$ 20,000$ a year would be erroneously seen as supporting household spending in that category, when in fact it was a contribution to a household with $\$ 70,000$ in income, where the primary source of income was $\$ 50,000$. Such an error would affect impact and multiplier analysis, because differences in spending patterns between household income levels can be substantial. For income distribution impacts, it means that a particular job can be "misallocated" in terms of the level of household income to which it contributes. The result evaluated here uses previously untapped data from the viewpoint of regional models to examine tourism's impact on local economic activity and income distribution from the more appropriate household viewpoint. 


\section{STUDY METHODS}

Input-output (I-O) models are the traditional vehicle used to examine the impact of a particular economic sector on the rest of that economy. I-O models examine the market flow of product between industries, sales by industries to households and other final consumers, and industry use of local labor and capital. Such models can be very detailed, consisting of several hundred industries, and have been used extensively to evaluate tourism-based economic activity (Miller and Blair 1985). A SAM provides a detailed picture of the economy but in a more complete fashion than an I-O model by explicitly accounting for all market and nonmarket (such as government welfare payments to households) income and resource flows. SAMs expand on I-O models by including local households, which are often divided into income categories. As a result, SAMs can track a given industry's impact on local household income distribution. That is, a properly constructed SAM provides a picture of local income distribution and how that distribution and the nature of local jobs may change as sectoral economic activity changes in level and composition.

The SAM used here is based on the approach outlined by Holland and Wyeth (1993) with the model formally defined as follows.

$$
\mathrm{Q}=\begin{array}{cc}
\mathrm{A} & \mathrm{H} \\
\mathrm{C} & \mathrm{I}
\end{array} \mathrm{V}=\begin{aligned}
& \mathrm{X} \\
& \mathrm{Y}
\end{aligned},
$$

where the matrix $\mathrm{V}$ contains the endogenous variables (as submatrices) $\mathrm{X}$, output, and $\mathrm{Y}$, income, and where $\mathrm{V}$ is pre-multiplied by the matrix $\mathrm{Q}$, which is comprised by $\mathrm{A}-\mathrm{a}$ submatrix of regional interindustry input coefficients, $\mathrm{H}$ (a submatrix of household regional consumption coefficients-industry by income class), I (an identity submatrix), and C (a submatrix of industry direct payment to households by income class coefficients. The key difference between our model and an I-O model is the detail found in $\mathrm{H}$ and C. (For further discussion see Holland and Wyeth 1993, among others.) The model can be used to evaluate not only the employment multipliers from tourism-based businesses, but also how such activity influences income distribution and other measures of local well-being.

More formally, we can look at the multiplier matrix, M3, derived from the model as follows.

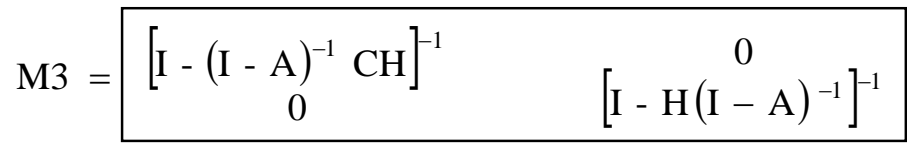

The upper left-hand cell in the partitioned matrix provides a set of input-output multiplier coefficients (analogous to the Leontief Inverse, closed with respect to households in input-output analysis, but with additional terms involving $\mathrm{C}$ and $\mathrm{H}$ ), while the lower right-hand cell provides a set of coefficients showing the final impacts on various household income classes. (In an input-output model, such detail is lacking.) 
In this study we construct a SAM model of the 31-county regional economy to evaluate the impact of Progress Fund-supported tourism activity on both income distribution and overall economic activity. Overall, the region can be described as classic rustbelt, with a strong need for economic restructuring more oriented towards growing parts of the U.S. economy. Hence, businesses supported by the Progress Fund could help the region shift to a new export base and enable needed economic restructuring in other ways.

Our model is based on the 2001 IMPLAN (IMpact analysis for PLANning) modeling system (Minnesota IMPLAN Group, Inc. 2000). IMPLAN is a commercial I-O modeling system that relies on secondary data, such as employment, and the assumption that input use and market distribution in the regional economy is similar to that found in the national economy. IMPLAN-based models also have hundred of industries; in this study, these sectors were aggregated into 42 industries.

For reasons detailed in Appendix A, we determined that the standard IMPLAN model was not appropriate for analyzing Progress Fund clients' economic impacts (i.e., it is not based on an appropriate C matrix). We create our SAM (that is, develop a fully specified $\mathrm{C}$ matrix) by estimating the relationship between industry and household income distribution using data drawn from the 5 percent Sample 2000 Census Public Use Microdata Series (PUMS) dataset (Alexander and Sobek 2005). We use the PUMS dataset in part because it places income on a household as opposed to individual basis.

Specifically, the PUMS dataset provides the advantage of linking earnings by individual household members by industry where data is provided for earned income for each household wage earner by industry. Also provided is total money income for that household unit. Based on this information, a household money income by industry dataset was formed. Using a two wage earning household as an example, assume one household wage earner worked in a manufacturing sector, such as automotive parts manufacture, while the other household wage earner worked in a tourism-oriented service sector, such as food and drinking establishments. For their particular household money income class, the household would have two row entries for their respective industries. For each household observation, a conversion was then made to households by personal income class, as described in Appendix A (primarily by accounting for the value of benefits). The relative values (i.e., normalized based on industry column totals) in the matrix were used to distribute earned income for a given set of appropriate IMPLAN-based industries. ${ }^{3}$

\footnotetext{
${ }^{3}$ PUMS data is based on an industry scheme that is very close in nature to the North American Industry Classification System (NAICS) at the three-digit level. We bridged from the PUMS industry scheme to NAICS and then assigned to IMPLAN sector based on the NAICS-IMPLAN bridging scheme provided in IMPLAN documentation. PUMS data is also provided by regions with at least 100,000 in population, which generally follow counties lines. More urbanized counties are broken into subareas; in rural areas, several counties usually form a given PUMS geographical region. We matched PUMS regions to our Progress Fund geographical coverage region for Pennsylvania in forming the PUMS dataset that was the core of our income distribution matrix.
} 


\section{RESULTS}

\subsection{Secondary Earned Income Analysis}

We use the PUMS data to evaluate the direct contribution of secondary earned income to total household income in two ways. First, we evaluate secondary income's importance by household income class. Then we examine the effects secondary household income has on a sector or industry basis.

As previously stated, households (as opposed to individuals) are the appropriate unit for analyzing decisions concerning work and, subsequently, industry impacts on income. Specifically, earned income from a secondary source can be an important part of the overall household financial strategy. It follows that such income should also be accounted for when examining how given industries impact income distribution. To wit, a given set of activities can make a strong contribution to middle- and upper-level household incomes. If this income is inaccurately treated as a primary source of income, resulting impacts on household income could also be misestimated. Fortunately, the PUMS dataset allows linking income earned by individuals to income earned by households.

Secondary income's contribution to total income was averaged across each income class. Averages across income classes fit a priori expectations; that is, as income class increases over a certain range, the relative contribution of secondary income also increases. The result is expected because two or more breadwinners should boost household income earning power. In fact, the existence of only one earner is a major contributing factor to poverty for many lower income households. At the highest income levels, however, one might expect secondary income's contribution to decline, as non-earned sources of income, such as investment income, comprise larger shares of total household income. Households with the highest income levels are also expected to more heavily value leisure over work, when evaluating such a tradeoff. For example, if one spouse earns $\$ 150,000$ per year, it is reasonable to expect the other spouse feels less compelled to participate in the formal labor market than he or she would if the primary breadwinner had less earning power. As shown in Figure 1, the relative contribution of secondary earned income to total earned income increases at a steady rate from the lowest household personal income level (under \$9,999), where the contribution is less than 1 percent, to the $\$ 75,000$ through $\$ 100,000$ level, where the contribution is 20.6 percent. For the two highest household income levels, the share of secondary earned income declines, falling to only 8.1 percent for the $\$ 150,000$ or greater household income level.

Our analysis of secondary-source income supports the hypothesis that tourism-related sectors are an important source of this income type. For example, 35.3 percent of earned household income in the $\$ 35,000$ to $\$ 50,000$ income class was secondary income from

museums, historical sites, zoos, and parks. For travel accommodations, 33.6 percent where income was in the $\$ 50,000$ to $\$ 75,000$ class and 39.8 percent in the $\$ 75,000$ to 


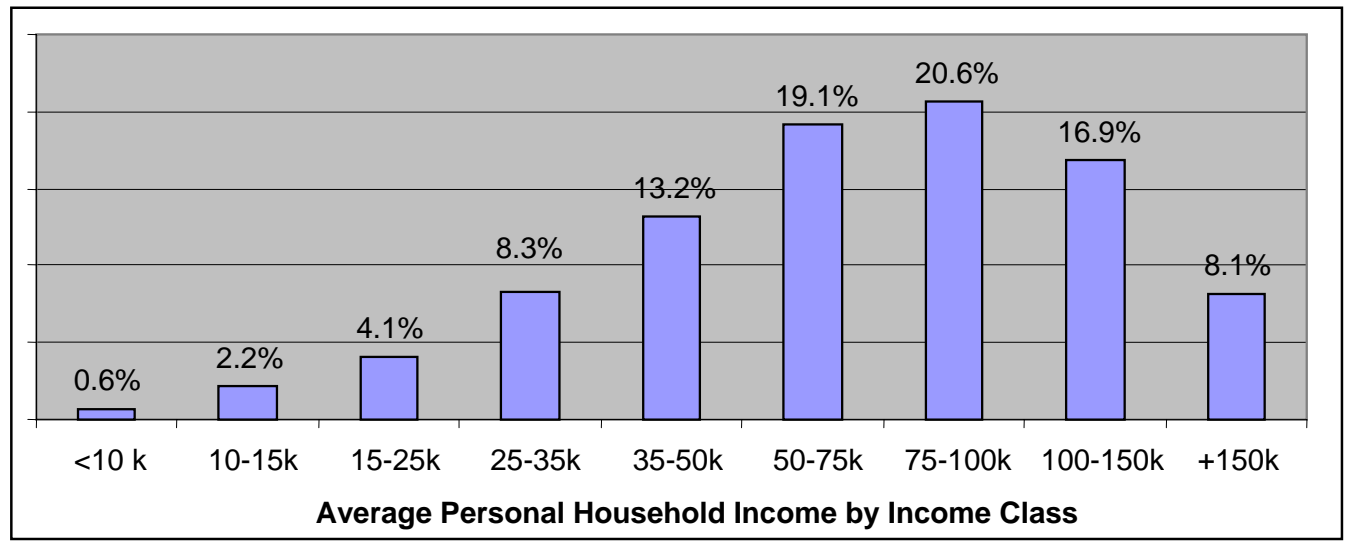

FIGURE 1. Relative Contribution of Secondary Earned Income by Household Personal Income Class

$\$ 100,000$ income class was generated by secondary income. ${ }^{4}$ For food service and drinking places, 51.1 percent of earned income in the $\$ 50,000$ to $\$ 75,000$ income class was secondary income. This result is possible because households can have more than one source of secondary income. ${ }^{5}$

\subsection{SAM Model Impact Results}

Results from the regional SAM shed light on several issues. First, the model helps us assess the impacts Progress Fund clients have on the regional economy. Specifically, we assess impacts on regional industry output, employment, and household income (total and by income class). We also develop alternative economic growth scenarios to compare the impact of Progress Fund clients on income distribution and overall activity.

\footnotetext{
${ }^{4}$ It is important to remember that the income generated by employment in the sector in question (travel accommodations in this case) is not necessarily at middle-income levels. Rather, secondary employment in the sector in question is shown to make a substantial contribution to earned income for the household income class in question ( $\$ 75,000$ to $\$ 100,000$ in this case). For example, the primary income could be generated by an occupation in a non-tourism industry with, say, $\$ 56,000$ in earned income, while $\$ 24,000$ in earned household income could be contributed by secondary employment in travel accommodations.

${ }^{5}$ The analysis of the PUMS data was also confirmed by a survey conducted of tourism businesses in the 31-county region of Pennsylvania and throughout West Virginia. Survey respondents were asked to indicate the number of employees by employment class (full-time, part-time, or seasonal) who were the primary providers of their households' income. Among 453 full-time employees, 282 (62.2 percent) were seen as being primary providers. For 488 part-time employees, only 124 (25.4 percent) were primary providers, and among the 822 seasonal employees, only 111 (13.5 percent) were seen as primary providers.
} 
Our Progress Fund area SAM consists of 42 sectors. Overall, we estimate Progress Fund clients directly provided 629 jobs and had revenues of \$30.853 million in 2006. These estimates were based on results from a survey of all Progress Fund clients (with a response rate of 64.8 percent), which was primarily conducted to assess satisfaction with the services provides to clients but also includes questions concerning estimates of level of sales and employment. Responding clients had the following sectoral breakdown: six each were classified as food service and other retail; five as accommodations; four each as other amusements and food and beverage stores; three as small manufacturing; two each as personal services, financial services, professional and business services, and personal services; and one each as educational services, social services, arts and entertainment, and museums. ${ }^{6}$ As an external reviewer points out, some of the Progress Fund clients would have significant non-tourism market segments. However, the Progress Fund leadership indicated that even manufacturing clients had a tourism market orientation. For example, one cheese manufacturer provides tours with tourism as a major market segment. Firms such as Wilderness Voyageurs (a cabin provider and rafting guide business classified in other services) and Jean Bonnet Tavern (food service) obviously have tourists as their primary market. Hence, our Progress Fund client shock serves as a proxy for tourism impacts and assumption we are comfortable with given their mission statement and the sectoral makeup of their clients. Still, we keep this caveat in mind when using study results to drawn conclusions about tourism.

We used the SAM multiplier matrix to estimate how Progress Fund clients effect other parts of the regional economy (Table 1 ). We estimate that $\$ 30.853$ million in direct revenues result in a total impact on local economic activity of $\$ 76.460$ million [or an output (revenue) multiplier of 2.48 per direct dollar of revenue] and 1,203 jobs (or a job multiplier of 1.92 total jobs generated per direct job). These impacts are spread throughout the economy, including food service and drinking places (\$10.059 million in output and 285 jobs), professional and business services (\$5.866 million and 107 jobs), other retail trade ( $\$ 4.213$ million in output and 88 jobs), food and beverage stores, and health services. While impacts in sectors such as other retail, food service and drinking places, and food and beverage stores are largely due to direct sales by Progress Fund clients, activity that occurs in professional and business services and health services are predominately secondary or spin-off in nature. In terms of the contribution of secondary earned income, it was especially strong for other retail trade starting at the $\$ 35,000$ through $\$ 50,000$ income class through higher income brackets and for food service and drinking places starting at the $\$ 25,000$ through $\$ 35,000$ income class.

For comparison purposes, we developed several alternative scenarios, including increases in sales by each sector as determined by their relative level of sales to final

\footnotetext{
${ }^{6}$ The entire regional economy has a strong emphasis in manufacturing (14.6 percent of employment), health and social services (11.0 percent), retail trade (13.2 percent), and government (13.2 percent). Hence, the Progress Fund clients had a much stronger presence in food service and services than the overall economy.
} 
consumers (final consumers scenario); ${ }^{7}$ sales increases in natural resource-based sectors (including the crop production, animal production, forest products, agriculture and forestry support activity, mining, and furniture and wood products sectors); and sales increases in nondurable manufacturing (including the food products, textile, apparel, leather goods, paper and printing products, petroleum and industrial chemicals, plastic and rubber products sectors). The total increase in direct sales for each of the three alternative scenarios was $\$ 30.853$ million (i.e., equal to total direct sales by Progress Fund clients). ${ }^{8}$ For the latter two scenarios, relative levels of industry output were used to distribute the $\$ 30.853$ million shock. The three alternative scenarios provide scale for the relative impact of Progress Fund clients on the regional economy and on income distribution. By providing these alternatives, we can evaluate the hypothesis that tourism jobs are less desirable than alternative economic growth scenarios because of impacts on household incomes (relatively low-paying jobs going by implication to low-income households).

Compared to Progress Fund clients, the three alternative scenarios all showed lesser regional economic impacts (Table 1). The natural resource based direct impact (\$30.583 million total) led to $\$ 61.868$ million in increase sales in the regional economy (for an output multiplier of 2.01) and 640 additional jobs (slightly more than half of the 1,203 jobs generated by Progress Fund clients' economic activity). Increased direct sales totaling \$30.853 million for nondurable manufacturing led to \$48.198 million in total revenues (for an output multiplier of 1.56) and 421 jobs throughout the regional economy (35.0 percent of the Progress Fund clients' impact). The final consumers scenario led to a projected \$54.704 million increase in local revenues (for an output multiplier of 1.77) and 795 jobs (66.1 percent of the level generated by the Progress Fund client impact scenario).

Impacts on jobs and output are also analyzed based on major sectors of the economy, including natural resources, construction, transportation and utilities, manufacturing, trade, finance and information, and services. The Progress Fund clients' impact on total revenue in the regional economy was concentrated in services at \$39.984 million (or 52.3 percent of the $\$ 76.460$ million total impact), manufacturing at $\$ 13.699$ million (17.9 percent), and trade at $\$ 10.297$ million (13.5 percent) (Figure 2). Given that Progress Fund clients are primarily service and trade sector businesses, the concentration of the impact in services was expected. However, the relative importance of the manufacturing impact was unexpected and may have resulted from the continued regional importance of the sector. Hence, spending by local businesses and households ultimately had a backward linked or multiplier effect impact on the regional manufacturing sector. Also, three of the Progress Fund clients are manufacturing establishments.

\footnotetext{
${ }^{7}$ Mathematically, this required normalizing the total final consumer vector by industry. Resulting industry shares were multiplied by the same value as estimated direct sales by Progress Fund clients (\$30.853 million) to arrive at this impact scenario.

${ }^{8}$ The latter two scenarios followed the procedure used by Leatherman and Marcouiller (1999).
} 
TABLE 1

Comparison of Changes in Output and Employment Under Alternative Growth Scenarios

\begin{tabular}{|c|c|c|c|c|c|c|c|c|}
\hline \multirow[b]{2}{*}{ Industry } & \multicolumn{2}{|c|}{ Progress Fund } & \multicolumn{2}{|c|}{ Consumers } & \multirow{2}{*}{$\begin{array}{r}\text { Resource } \\
\text { Output (M \$) }\end{array}$} & \multirow[b]{2}{*}{ Jobs } & \multicolumn{2}{|c|}{ Manufacture } \\
\hline & Output (M \$) & Jobs & Output (M \$) & Jobs & & & Output (M \$) & Jobs \\
\hline Crop Production & 0.319 & 7 & 0.353 & 7 & 2.999 & 62 & 0.463 & 10 \\
\hline Animal Production & 0.676 & 12 & 0.587 & 11 & 5.086 & 92 & 1.396 & 25 \\
\hline Forest Products & 0.156 & 1 & 0.035 & 0 & 3.434 & 24 & 0.721 & 5 \\
\hline Agricultural Support & 0.036 & 1 & 0.033 & 1 & 0.689 & 26 & 0.110 & 4 \\
\hline Mining & 0.796 & 4 & 0.744 & 3 & 16.165 & 76 & 0.682 & 3 \\
\hline Utilities & 1.511 & 4 & 1.577 & 5 & 0.778 & 2 & 0.715 & 2 \\
\hline Construction & 0.652 & 8 & 0.309 & 4 & 0.161 & 2 & 0.165 & 2 \\
\hline Food Products & 3.022 & 10 & 2.561 & 8 & 1.130 & 4 & 6.758 & 22 \\
\hline Textile, Apparel, Leather & 0.286 & 2 & 0.576 & 4 & 0.243 & 2 & 3.464 & 25 \\
\hline Furniture, Wood Products & 1.543 & 12 & 0.271 & 2 & 11.709 & 89 & 5.693 & 43 \\
\hline Paper and Printing Products & 0.006 & 0 & 0.008 & 0 & 0.004 & 0 & 5.975 & 29 \\
\hline Petroleum, Chemicals & 1.176 & 2 & 0.973 & 2 & 1.353 & 3 & 1.763 & 3 \\
\hline Plastic and Rubber Products & 0.939 & 5 & 0.632 & 4 & 0.660 & 4 & 6.179 & 36 \\
\hline Nonmetal Mineral Products & 0.302 & 2 & 0.178 & 1 & 0.222 & 1 & 0.196 & 1 \\
\hline Primary, Fabricated Metal Products & 1.714 & 11 & 0.039 & 0 & 0.080 & 0 & 0.076 & 0 \\
\hline Machinery Manufacture & 3.626 & 24 & 0.183 & 1 & 0.551 & 4 & 0.212 & 1 \\
\hline Computer, Electrical Equipment & 0.807 & 5 & 0.934 & 5 & 0.479 & 3 & 0.577 & 3 \\
\hline Transportation Equipment & 0.137 & 1 & 0.255 & 1 & 0.081 & 0 & 0.080 & 0 \\
\hline Miscellaneous Manufacture & 0.140 & 1 & 0.236 & 1 & 0.060 & 0 & 0.073 & 0 \\
\hline Wholesale Trade & 2.985 & 29 & 1.866 & 18 & 1.418 & 14 & 1.480 & 14 \\
\hline Air transportation & 0.070 & 0 & 0.132 & 1 & 0.036 & 0 & 0.054 & 0 \\
\hline Other Transportation & 1.799 & 15 & 1.781 & 15 & 1.613 & 14 & 1.566 & 13 \\
\hline Ground Passenger Transportation & 0.115 & 4 & 0.181 & 6 & 0.055 & 2 & 0.067 & 2 \\
\hline Scenic, Sightseeing Transportation & 0.074 & 1 & 0.076 & 1 & 0.052 & 1 & 0.077 & 1 \\
\hline Other Retail Trade & 4.213 & 88 & 5.110 & 107 & 1.257 & 26 & 0.980 & 20 \\
\hline Food and Beverage Stores & 2.744 & 64 & 1.101 & 26 & 0.277 & 6 & 0.235 & 6 \\
\hline Gasoline Stations & 0.181 & 4 & 0.398 & 8 & 0.094 & 2 & 0.094 & 2 \\
\hline Information, Communication & 0.939 & 6 & 1.285 & 8 & 0.404 & 3 & 0.355 & 2 \\
\hline Financial Activity & 5.527 & 52 & 6.379 & 59 & 3.626 & 34 & 1.926 & 18 \\
\hline
\end{tabular}




\begin{tabular}{|c|c|c|c|c|c|c|c|c|}
\hline \multirow[b]{2}{*}{ Industry } & \multicolumn{2}{|c|}{ Progress Fund } & \multicolumn{2}{|c|}{ Consumers } & \multirow{2}{*}{$\begin{array}{r}\text { Resource } \\
\text { Output (M \$) }\end{array}$} & \multirow[b]{2}{*}{ Jobs } & \multicolumn{2}{|c|}{ Manufacture } \\
\hline & Output (M \$) & Jobs & Output (M \$) & Jobs & & & Output (M \$) & Jobs \\
\hline Professional, Business Services & 5.866 & 107 & 3.048 & 56 & 2.002 & 37 & 1.681 & 31 \\
\hline Personal Services & 2.457 & 70 & 2.872 & 81 & 1.213 & 34 & 1.132 & 32 \\
\hline Educational Services & 2.403 & 69 & 1.010 & 29 & 0.259 & 7 & 0.221 & 6 \\
\hline Health Services & 4.198 & 51 & 9.706 & 119 & 2.195 & 27 & 1.642 & 20 \\
\hline Social Services & 0.519 & 18 & 0.625 & 21 & 0.136 & 5 & 0.123 & 4 \\
\hline Arts and Entertainment & 0.189 & 9 & 0.099 & 5 & 0.079 & 4 & 0.050 & 2 \\
\hline Museums Parks, Related & 0.839 & 15 & 0.044 & 1 & 0.009 & 0 & 0.029 & 1 \\
\hline Other Amusement Services & 3.977 & 135 & 0.491 & 17 & 0.129 & 4 & 0.110 & 4 \\
\hline Hotels and Motels & 0.248 & 5 & 0.230 & 4 & 0.087 & 2 & 0.107 & 2 \\
\hline Other Accommodations & 8.682 & 58 & 0.140 & 1 & 0.032 & 0 & 0.046 & 0 \\
\hline Food Services, Drinking Places & 10.059 & 285 & 2.971 & 84 & 0.742 & 21 & 0.606 & 17 \\
\hline Government and Other & 0.359 & 5 & 4.417 & 60 & 0.200 & 3 & 0.245 & 3 \\
\hline Total & 76.460 & 1,203 & 54.704 & 795 & 61.868 & 640 & 48.198 & 421 \\
\hline
\end{tabular}




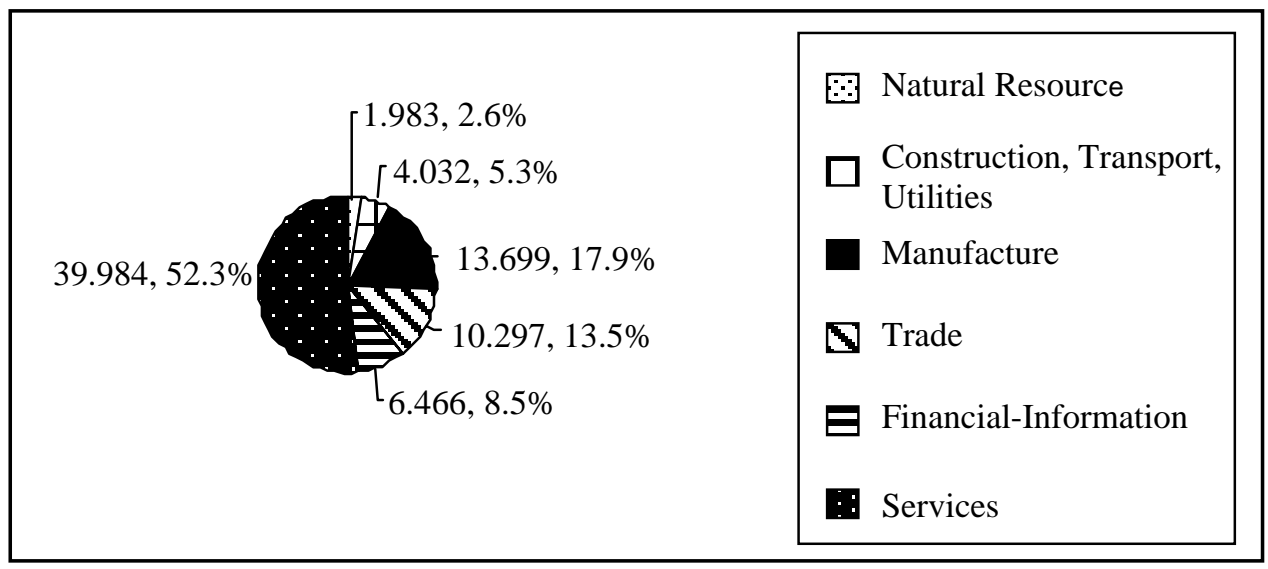

FIGURE 2. Output Impact by Aggregate Sector, Progress Fund Scenario (M\$)

Progress Fund clients' impacts on regional employment were also concentrated in services (831 jobs or 69.0 percent of the 1,203 total employment impact), followed by trade (189 jobs/15.7 percent), manufacturing (73 jobs/6.1 percent), and financial and information activity (57 jobs/4.8 percent) (Figure 3). Compared to the regional revenue estimates generated by Progress Fund clients, the relatively large share of job impacts in services and trade is expected, given that both sectors employ comparatively larger numbers of workers per dollar of revenue.

Model results also indicate that the Progress Fund clients' impact on total regional household income was larger than for any other scenario (Table 2). Analysis of the various purchasing patterns shows this outcome was due to a greater concentration of client business spending going to local households as opposed to the other sectors, especially nondurable manufacturing. In other words, household spending has less immediate leakage compared to business spending because household expenditures are more likely dedicated to regionally produced services. In our scenarios, local household income increased by $\$ 30.583$ million due to activity by Progress Fund clients as compared to $\$ 12.578$ for the nondurable manufacturing scenario, \$16.923 million for the natural resource scenario, and \$21.657 million for the final consumers scenario.

Model results also show that Progress Fund clients have a larger impact on household income, regardless of income class (Table 2). For ease of exposition, we collapsed the nine income classes in the model into three aggregate classes (less than $\$ 25,000, \$ 25,000$ through $\$ 75,000$, and greater than $\$ 75,000$ ). For each household income group, the Progress Fund client scenario showed a greater gain than any alternative scenario. For example, households with personal income levels greater than $\$ 75,000$ received an estimated increase in income of \$11.194 million under the Progress Fund client scenario, 74.4 percent greater than the natural resource based impact of $\$ 6.418$ million for the same income class. For the middle income group $(\$ 25,000$ through $\$ 75,000)$, the Progress Fund clients impact scenario showed a gain of \$13.564 million compared to an estimated 
increase of $\$ 8.117$ million for the natural resource based impact scenario and 31.0 percent greater than the $\$ 8.544$ million for the final consumers impact scenario. For households with less than $\$ 25,000$ in personal income, the Progress Fund client impact scenario led to a projected $\$ 5.825$ million gain in aggregate income compared to $\$ 3.317$ million for the final consumers scenario.

We turn now to relative distributional impacts. In percentage terms, household personal income impacts for Progress Fund clients are largely concentrated in the lowest personal household income class at 19.0 percent (Table 2). However, the comparisons were more mixed for the other income classes. For example, Progress Fund clients' impact showed a slightly higher return to the highest income class compared to the nondurable manufacturing impact (36.6 versus 36.3 percent). For impacts on household personal income in the middle personal income range $(\$ 25,000$ through $\$ 75,000)$, the Progress Fund clients scenario showed only a slightly lower percentage return in comparison to the final consumers (44.4 percent versus 45.2 percent) scenario. These results indicate that the Progress Fund clients scenario was skewed toward the lowest household personal income group, but only slightly so, a result consistent with the findings of Leatherman and Marcouiller (1999).

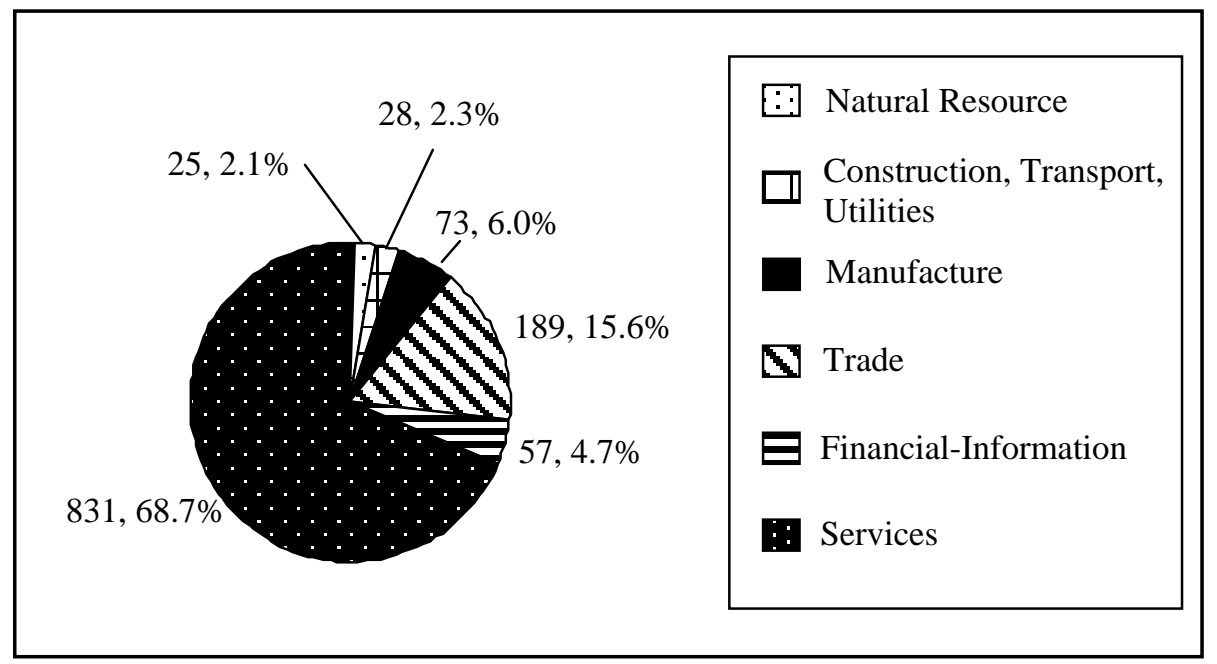

FIGURE 3. Job Impacts by Aggregate Sector, Progress Fund Scenario 
TABLE 2

Comparison of Changes in Household Income Under Alternative Growth Scenarios

\begin{tabular}{|c|c|c|c|c|c|c|c|}
\hline \multirow[b]{2}{*}{ Household Income Impacts, \$M } & \multicolumn{4}{|c|}{ Change in Household Income Class (\$M) } & \multicolumn{3}{|c|}{ Progress Fund Versus } \\
\hline & Progress Fund & Consumer & Resource & Manufacture & Consumer & Resource & Manufacture \\
\hline Less than $\$ 25,000$ & 5.825 & 3.317 & 2.389 & 1.855 & $175.6 \%$ & $243.8 \%$ & $314.0 \%$ \\
\hline$\$ 25,000-\$ 75,000$ & 13.564 & 9.796 & 8.117 & 6.156 & $138.5 \%$ & $167.1 \%$ & $220.3 \%$ \\
\hline Greater Than $\$ 75,000$ & 11.194 & 8.544 & 6.418 & 4.567 & $131.0 \%$ & $174.4 \%$ & $245.1 \%$ \\
\hline Total & 30.583 & 21.657 & 16.923 & 12.578 & $141.2 \%$ & $180.7 \%$ & $243.1 \%$ \\
\hline $\begin{array}{l}\text { \% Income Distribution, } \\
\text { Household Income Impacts }\end{array}$ & & & & & & & \\
\hline Less than $\$ 25,000$ & $19.0 \%$ & $15.3 \%$ & $14.1 \%$ & $14.7 \%$ & $124.3 \%$ & $134.9 \%$ & $129.2 \%$ \\
\hline$\$ 25,000-\$ 75,000$ & $44.4 \%$ & $45.2 \%$ & $48.0 \%$ & $48.9 \%$ & $98.1 \%$ & $92.5 \%$ & $90.6 \%$ \\
\hline Greater Than $\$ 75,000$ & $36.6 \%$ & $39.4 \%$ & $37.9 \%$ & $36.3 \%$ & $92.8 \%$ & $96.5 \%$ & $100.8 \%$ \\
\hline
\end{tabular}




\section{SUMMARY AND CONCLUSIONS}

In this study we examined the economic and distributional impacts of clients of the Progress Fund-a CDFI located in Pennsylvania—on a 31-county (rural) regional economy. Recognizing that tourism-related employment often provides households with supplemental income, we emphasized the special role of secondary income. We estimated these effects using a regional SAM model and constructed three scenarios to compare tourism's contribution with alternative growth paths. Compared to the alternatives, we found that Progress Fund-related activity had the largest regional impact on revenues, employment, and total household income. When examining aggregate impacts by household income categories, we found that Progress Fund clients' activity contributed moreboth directly and indirectly - to each income class than did any of the three alternative growth scenarios. However, examining the beneficiaries of activity by Progress Fund clients shows that the distributional impact was slightly skewed toward lower-income households (income levels less than $\$ 25,000$ ) as compared to all three alternative scenarios. In comparison to some alternative growth scenarios (specifically, nondurable manufacturing), activity by Progress Fund clients was slightly more skewed toward the highest income class (\$75,000 and up). Accordingly, activity by Progress Fund clients may contribute slightly to the hollowing out process described by Leatherman and Marcouiller (1999).

This research raises important questions about the role of tourism-based businesses and activities in regional or local economic and community development efforts. In particular, heritage-type tourism activity has the potential for making a place more livable. Further, emerging research indicates that amenities are important in developing certain types of desirable economic activity, such as high-tech. We did not investigate the relationship between heritage tourism and other forms of desirable local tourism assets. In as much as activity by Progress Fund clients enhances local amenities for a given community or region, the local economy could also benefit.

Given the limitation that some Progress Fund clients are not totally reliant on tourism as a market, this research informs a number of important debates about the desirability of tourism-based economic development. Most noteworthy is that we find that the tourism industry can have substantial impacts on both regional employment and income, at levels that may be greater than those offered by other industries promoted in rural development programs. Secondary income that the sector provides to many households is one of the mechanisms for this outcome. Whereas manufacturing and other basic industries are subject to relatively high leakages, households are the main beneficiaries of tourism development, with much of the money thus remaining in the local economy, at least in early rounds of multiplier spending.

However, tourism's skeptics do have some standing, especially with respect to concerns about the effects on income distribution. Here, we find that many of the benefits are concentrated in low-income households, suggesting that many of the jobs are not necessarily "good" jobs. Alternatively, because these are often secondary jobs for a household, 
this concern may not be terribly worrisome, as the common criticisms of the jobs (e.g., part-time and seasonal) may be a desired attribute for many households. In this regard, a fruitful area for future research would be how households view employment in tourismtype activities. While it is certainly not a panacea for rural areas, a properly implemented tourism-based economic development strategy can be a viable and important complement to overall regional development efforts, especially for areas with limited options.

\section{REFERENCES}

Albretch, D.E., 1998. "The Industrial Transformation of Farm Communities: Implications for Family Structure and Socioeconomic Conditions,” Rural Sociology 63(1), 51-64. , 2000. "Recreational and Tourism Development vs. the Decline of Agriculture in Southern Utah,” in P.V. Schaeffer and S. Loveridge (eds.), Small Town and Rural Economic Development: A Case Study Approach. Praeger: Westport, CT.

Alexander, A.J. and M. Sobek, 2005. "Using the Integrated Public Use Microdata Series in Research (IPUMS)," Paper Presented at the ASA (American Sociological Association) Annual Meetings, Philadelphia, PA.

Alward, G., 1996. “Deriving SAM Multiplier Models Using IMPLAN,” Paper presented at the National IMPLAN Users Conference, Minneapolis, MN.

Dawson, C.P. and T.L. Brown, 1989. "Bed and Breakfast Business Programming: Program Development and Evaluation,” Journal of Extension 27(2), 26-27.

Fleischer A. and D. Felsenstein, 2000. "Support for Rural Tourism: Does it Make a Difference?” Annals of Tourism Research 27(4), 1007-1024.

Fleisher, A. and A. Pizam, 1997. "Rural Tourism in Israel," Tourism Management 18(6), 367-372.

Frederick, M., 1993. "Rural Tourism and Economic Development,” Economic Development Quarterly 7(2), 215-224.

Garrett, P., N. Ng'andu, and J. Ferron, 1994. "Is Rural Residency a Risk Factor for Childhood Poverty?” Rural Sociology 59(1), 66-83.

Goreham, L., 1992. “The Growing Problem of Low Earnings in Rural Areas,” in C.M. Duncan (ed.), Rural Poverty in American. Auburn House: New York.

Holland, D. and P. Wyeth, 1993. "SAM Multipliers: Their Decompostion, Intrepretation and Relationship to Input-Output Multipliers,” Research Bulletin XB1027, Dept. of Agricultural Economics, Washington State University: Pullman, WA.

Jensen, L and D.J. Eggebeen, 1994. "Nonmetropolitan Poor Children and Reliance on Public Assistance,” Rural Sociology 59(1), 45-65.

Jensen, L. and M. Tienda, 1989. "Nonmetropolitan Minority Families in the United States: Trends in Racial and Ethnic Economic Stratification, 1959-1986," Rural Sociology 54(4), 509-532.

Leatherman, J.C. and D.W. Marcouiller, 1999. "Moving Beyond the Modeling of Regional Growth: A Study of How Income is Distributed to Rural Households," Economic Development Quarterly 13(1), 38-45.

Lee, D.W., and S. Kang, 1999. "Measuring Earnings Inequality and Median Earnings in the Tourism Industry,” Tourism Management 19(4), 341-348. 
Lipman, G., 1997. “Creating Jobs for the Future,” World Travel \& Tourism Development 02, 16.

Lichter, D.T., 1989. "Race, Employment Hardship, and Inequality in the American Nonmetropolitan South,” American Sociological Review 54(3), 436-446.

Marcouiller, D.W., K-K Kim, and S.C. Deller, 2004. "Natural Amenities, Tourism, and Income Distribution,” Annals of Tourism Research 31(4), 1031-1050.

Miller, R.E. and P.D. Blair, 1985. Input-Output Analysis: Foundations and Extensions. Prentice-Hall Inc.: Engelwood Cliffs, NJ.

Minnesota Extension Service, Tourism Center, 1991. “A Training Guide for Rural Tourism Development,” Extension Publication CD-EP-5666 CD-MI-5668 269, University of Minnesota: St. Paul.

Minnesota IMPLAN Group, Inc., 2000. IMPLAN Professional Version 2.0 User's Guide, Analysis Guide and Data Guide: Stillwater, MN.

Olson, D, 2007. “Why is Personal Income for my Region So High?” Minnesota Income Group. Available at www.implan.com/documents/Personal_vrs_Money_Income.pdf, February.

Progress Fund Website, 2007. Available at www.progressfund.org/main.htm, February.

U.S. Department of Commerce, Bureau of Economic Analysis, 2000. "Regional Economic Information System CD-ROM, 1969-1998,” Washington, D.C. , 2001. "Comprehensive Revision of State Personal Income: Revised Estimates for 1969-98, Preliminary Estimates for 1999,” Available at www.bea.gov/bea/regional/ articles/0600spi/maintext.htm, February.

U.S. Department of Commerce, Small Business Administration, Office of Advocacy, 2005. "Factsheet," Available at www.sba.gov/advo/laws/comments/factsstate05_ 1031.pdf, February.

U.S. Social Security Administration. Social Security on-line, 2005. Available at www. ssa.gov/notices/supplemental-security-income/, February.

Wagner, J.E., 1997. "Estimating the Economic Impacts of Tourism,” Annals of Tourism Research 24(3), 592-608.

Wanhill, S., 2000. "Small and Medium Tourism Enterprises," Annals of Tourism Research 27(1), 132-147.

\section{APPENDIX}

\section{Construction of SAM Model}

A properly delineated SAM is crucial to our analysis. Accordingly, one important change to the original IMPLAN SAM concerns payments to labor (employee compensation in IMPLAN) and payments to owner-operators (proprietors' income in IMPLAN, which is a mixture of returns to capital and labor). In terms of consumption and aggregate non-market income flows, the original IMPLAN SAM reports household interactions with the rest of the economy by dividing households into nine income groups (ranging from under $\$ 10,000$ to over $\$ 150,000$ ). However, for employee compensation and proprietors' income, payments to each household type are placed in a common income pool (i.e., payments to labor and returns to proprietors at the industry level form a single row, 
or the matrix $\mathrm{C}$ is reduced to a one dimensional matrix multiplied by an identity matrix for conformability). Total payments are then allocated to the nine income households based on fixed income shares. Any change in earnings by a particular industry is treated as a regional average income change across the nine groups. But the distribution of earnings between income levels can vary markedly among different regional industries; thus model estimates of industry and policy changes on income distribution could be biased (Alward 1996).

We tackled this problem by constructing an income distribution matrix linking payments to labor by industries to households by their personal income class (i.e., our $\mathrm{C}$ matrix). Generating the income distribution matrix was a daunting task because personal income is comprised of both money and nonmoney income (Olson 2007). Based on national data provided in Olson, money income only constitutes 75 percent of personal income (or personal income is 35 percent larger than money income). Estimates of money income by class can be obtained — at least at the state level—by income class for workers in a variety of industries. A more difficult task is to construct a reasonably accurate way of distributing nonmoney income to households by income class on the incomeearning (as opposed to consumption) side.

As discussed in the text, we used the Integrated Public Use Microdata Series (PUMS) dataset (Alexander and Sobek 2005) to estimate the relationship between industry and household by money income class for the Progress Fund region of Pennsylvania. The PUMS dataset is based on the 5 percent sample from the ten-year census, meaning we relied on 2000 data.

We then estimated the relationship between money household income and the various forms of nonmoney, personal income by money household income group. That is, how much nonmoney income does a typical household in a given money income class receive from a specific source, such as food stamps? A possible limitation of such an approach is that the estimates of these relationships are generally based on national data. This requires the assumption that within an income class, behavior at the state or regional level is the same as found nationally. While we believe that this is a reasonable assumption, it is also eased to a certain extent by the use of a regional control total in several different ways. First, data sources such as the Regional Economic Information System provided by the Bureau of Economic Analysis, U.S. Department of Commerce (2000) usually provide regional control totals indicating the total level of nonmoney payments. Further, based on annual censuses and other data sources, IMPLAN provides an estimate of personal income by income class (Olson 2007). These estimates are used to drive household spending in the model. Hence, our procedure of building up from the PUMS data yields estimates that must ultimately be reconciled with these other data sources.

Personal income excluded from money income is generally "payments" made to or on behalf of individuals but do not go to the individual as immediate money income. For example, employer payments to government employee retirement plans and to private health and pension plans form nonlabor income as part of personal income. These pay- 
ments are not included in money income. Transfer payments are an important part of personal income and money income. However, the value of in-kind transfer payments are included in personal income but excluded from money income (e.g., Medicaid and Medicare are payments made to medical service providers on behalf of individuals). These payments are treated as income in personal income but are not money income. Food stamps are another form of in-kind payments to individuals. Various types of imputed income (the valuation of a "free" service or a capital consumption) are also included in personal income but not money income (U.S. Dept. of Commerce, BEA 2001).

Money income also includes some income that is excluded from personal income. This includes income sources that are personal contributions for social insurance, various forms of retirement income from government worker retirement plans and private pensions and annuities, and certain interpersonal income transfers such as child support payments (U.S. Dept. of Commerce, BEA 2001).

Of these exclusions, the contribution to social insurance is the most important. We adjusted money income levels based on income class and the rules for social security contribution income limits for 2001 (U.S. Social Security Administration 2003). We also limited our use of the PUMS data to positive earnings only, thus reducing the import of any type of current retirement money payment.

Other labor income forms one part of the nonmoney personal income flow to households from industries primarily in the form of employee insurance and retirement benefit payments. Also accounted for were appropriate payments to retirement accounts, accumulation of interest income in accounts, a valuation of owner-occupied housing, and the value of food stamps and Medicaid payments.

The adjustment values were used to scale the individual estimates from the PUMS data. By working on the individual observation level, households could move between income classes in going from money to personal income. For example, households in the higher end of the $\$ 35,000$ to $\$ 50,000$ money income class would move into the $\$ 50,000$ $\$ 75,000$ personal income class. Households in the lower end of the $\$ 35,000$ to $\$ 50,000$ income class would not shift to a higher personal income class. 